\title{
Media Representations of Gender And Leadership: From a Discourse Perspective
}

\begin{abstract}
This article explores the media representations of gender and leadership by examining the interactional data drawn from the U.S. reality TV show The Apprentice. By taking a discourse perspective, this article looks at the ways in which two project managers 'do leadership' as portrayed in the TV show. The analysis shows that both managers draw upon elements of a masculine speech style as well as feminine discourse features for the performance of leadership. However, while the use of 'mixed' gendered discourse features by the male manager is portrayed in a positive light in the reality TV show, similar verbal behaviours by the female manager are viewed rather negatively by other contestants. It is suggested that owing to the stereotypical expectations of gender-appropriate behaviours and the traditional association of leadership with masculinity, the female manager may be under more constraints when using 'mixed' gendered discursive strategies in 'doing leadership', while the male manager may be allowed to use a greater range of acceptable verbal behaviours when enacting the role of a leader.
\end{abstract}

\section{Key words}

Gender; leadership; discourse analysis; sociolinguistics; media; reality TV

\section{Introduction}

Over the last few decades, there has been a growing body of research into language and gender representations in the media (Gill 2006; Talbot 2010; Sung 2011, 2012). One reason for the interest in this area of research is that media representations often play an important role in shaping the ways in which the audience understand and make sense of the social world, including gender and 
power relations (Evans 2005). In particular, the media may contribute to the audience's perceptions of what constitutes appropriate gendered behaviour for men and women (Matheson 2005; Gill 2006; Ross 2010). Some feminist scholars, for example, have expressed concerns about the socializing and normalizing consequences of stereotypical representations of men and women in the media, given that the media are important sites of representation, construction and contestation of gendered identities and ideologies (Litosseliti 2006). In view of the potential influence of the media on the audience's perceptions of gender and workplace communication, this article explores the representations of gender and leadership discourse in the 'simulated' workplace as portrayed in the popular reality TV show The Apprentice.

\section{Discourse, gender and leadership}

In tune with the social constructionist approach (Butler 1990), gender is conceived of as a social construction, rather than a 'given' social category. In other words, gender is conceptualized as a dynamic performance or social practice (Talbot 2010). In particular, emphasis is placed on the diverse, flexible and contextresponsive ways in which people 'do gender' in different situations, and even from moment to moment within the same situation (Holmes and Marra 2010).

As people construct their gender identities, they draw upon discourse styles which may be indexed as 'gendered' (Holmes 2006; Schnurr 2009; Talbot 2010). According to Ochs (1992), gender is indirectly indexed, whereby discursive and linguistic choices are associated with certain stances, roles or practices, which are in turn associated with gender. For example, masculine styles of interaction are characterized by competitive, contestive and challenging ways of speaking, whereas feminine speech styles are characterized by co-operative, facilitative and smooth interaction (Holmes 2006; Schnurr 2009). Specifically, masculine speech styles are often discursively realized in the production of extended speaking turns, the dominance of the speaking floor, the one-at-a-time construction of the floor, and the frequent use of interruptions (Coates 1997, 2004; Schnurr 2009; Talbot 2010). On the other hand, feminine discourse styles, which place emphasis on the relational aspects of the interaction, are linguistically expressed through the collaborative construction of the floor in conversation, avoidance of confrontations, and the use of politeness strategies and hedging devices, as well as minimal responses and supportive feedback (Holmes 1995; Coates 2004; Sunderland 2004; Talbot 2010). It should be noted, however, that the binary distinction between masculine and feminine speech styles clearly neglects the influence of other social variables and the role of contexts in shaping language use (Holmes 2006). Nonetheless, such a distinction is important because it captures the typical discourse elements that people often associate with masculine and feminine verbal behaviours (Holmes and Stubbe 2003). It can also be useful in understanding how people construct and enact their gender identities in discourse (Schnurr 2010, Sung 2013). 
Like gender, leadership is seen as a process or a performance, rather than merely as the outcomes or achievements of a leader (Holmes et al. 2003; Holmes 2006; Baxter 2010; Schnurr 2010). By taking a discourse perspective, I am particularly interested in the language of 'doing leadership', or 'leadership discourse'. According to Holmes et al. (2003: 32), “'doing leadership' entails competent communicative performance which, by influencing others, results in acceptable outcomes for the organization (transactional/task-oriented goal), and which maintains harmony within the team (relational/people-oriented goal)". It is noteworthy here that Holmes et al.'s (2003) definition of leadership focuses on the communicative aspects of 'doing leadership' and draws attention to both transactional and relational aspects of doing leadership.

As Marra et al. (2006: 240) suggest, leadership is a "gendered concept". As leadership positions in different workplaces have traditionally been dominated by men, masculinity is often indexed indirectly via the doing of leadership (Sinclair 1998). As Hearn and Parkin (1989: 21) note, "the language of leadership often equates with the language of masculinity to include qualities such as aggression, assertiveness, abrasiveness, and competitiveness". Martin Rojo and Gomez Esteban (2005) also make a similar point that the criteria used to measure competence in leadership continue to be associated with the male stereotypes. It is therefore generally accepted that a masculine discourse style is still represented as the default and preferred way of doing leadership. With reference to Holmes et al.'s (2003) definition of leadership, while communicative behaviours concerned with transactional or task-oriented goals are closely linked with masculinity, verbal behaviours oriented to more relational or people-oriented goals are associated with femininity (Holmes 2006; Marra et al. 2006; Schnurr 2009). As regards the discursive characteristics of communication associated with these differently gendered leadership behaviours, Marra et al. (2006) and Schnurr (2009) point out that whereas normatively masculine strategies of leadership are characterized by assertiveness, directness, competitiveness, display of power, dominance, individualism, and task-orientation, a normatively feminine speech style of leadership is characterized by indirectness, politeness, collaborativeness, supportiveness, nurturing, caring, egalitarianism, and relationship-orientation (see also Holmes and Stubbe 2003).

\section{Data: The Apprentice (2004)}

The interactional data used in the study are drawn from the debut season of The Apprentice (2004), a popular reality TV show in the United States. In its debut season, sixteen contestants compete in an elimination-style competition, vying for the top job at one of Donald Trump's companies with its $\$ 250,000$ salary. During the 15 episodes of the show, they embark upon a televised, extended job interview in order to become an apprentice of Donald Trump, a well-known American real estate magnate as well as host and executive producer of The Ap- 
prentice. In the show, each team is required to select a project manager to lead them in the assigned task of the week. The two teams compete against each other every week in a business-oriented task which is intended to test their business skills and expertise. Every week, the winning team is rewarded spectacularly, while the losing team faces Donald Trump in the boardroom, where the reasons for the failure in the task are discussed. At the end of each episode, Donald Trump makes the decision on who did the worst job in the losing team and, consequently, should be fired with immediate effect. Given its popularity in the United States and around the world, The Apprentice can be considered an invaluable site for investigating media representations of workplace communication, especially in relation to leadership and gender.

Indeed, one of the main themes in The Apprentice is leadership, which is also one of the main criteria in choosing the 'apprentice' from the sixteen contestants. In the course of analyzing the TV show, it is not difficult to find traces of a 'battle of the sexes' discourse in the representations of gender and leadership (Sunderland 2004). In particular, such a discourse places emphasis on an essential social tension and competition between men and women as a whole in society, particularly in their performance at work. As Sunderland (2004: 43) notes, implicit in the discourse is "the sexist construct that any gains of one group must be at the expense of the other". Clearly, the division of the contestants into two teams based on gender in The Apprentice is a prime example of reproducing the "battle of the sexes' discourse prevalent in popular culture. It should therefore be remembered that the TV show does not simply present the reality, but may intend to dramatize the 'reality' in order to attract a large audience for commercial purposes. As shown in Excerpt 1 below, the gendering of the two teams is made explicit at the beginning of the reality TV show by Donald Trump in Episode 1.

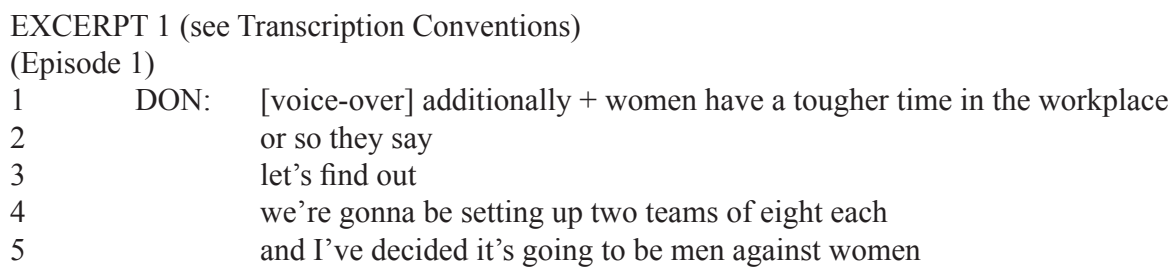

In this article, I shall only focus on two project managers in the TV show for the sake of space, namely Omarosa and Kwame. In particular, these managers are chosen for analysis because they are shown to be engaged in acts of 'doing leadership' and because their leadership performance is evaluated by other contestants in the TV show. Another reason for the choice is that their leadership discourse is considered analyzable in the sense that it constitutes a coherent, meaningful, and typically continuous stretch of talk. Although numerous interactions in the show are potentially useful for analysis, they are piecemeal in nature. For example, they might be cut off by the insertion of particular individual interviews and do not form a continuous stretch of interaction. As such, these interactions are not 
chosen for analysis. In what follows, I shall present an analysis of how these two managers draw upon different gendered linguistic features and discourse strategies when 'doing leadership' and how their leadership performance is perceived and evaluated by other contestants in the TV show.

\section{Data analysis}

\subsection{Analysis of Omarosa's leadership discourse}

I shall first look at the performance of leadership by the female project manager, Omarosa. In the next excerpt below, Omarosa is in a cab with Heidi, and she receives a phone call from Jessie and Kwame, who request Omarosa to get them the number of the foundation which they are going to work with. However, Omarosa rejects their requests in a relatively masculine discursive style.

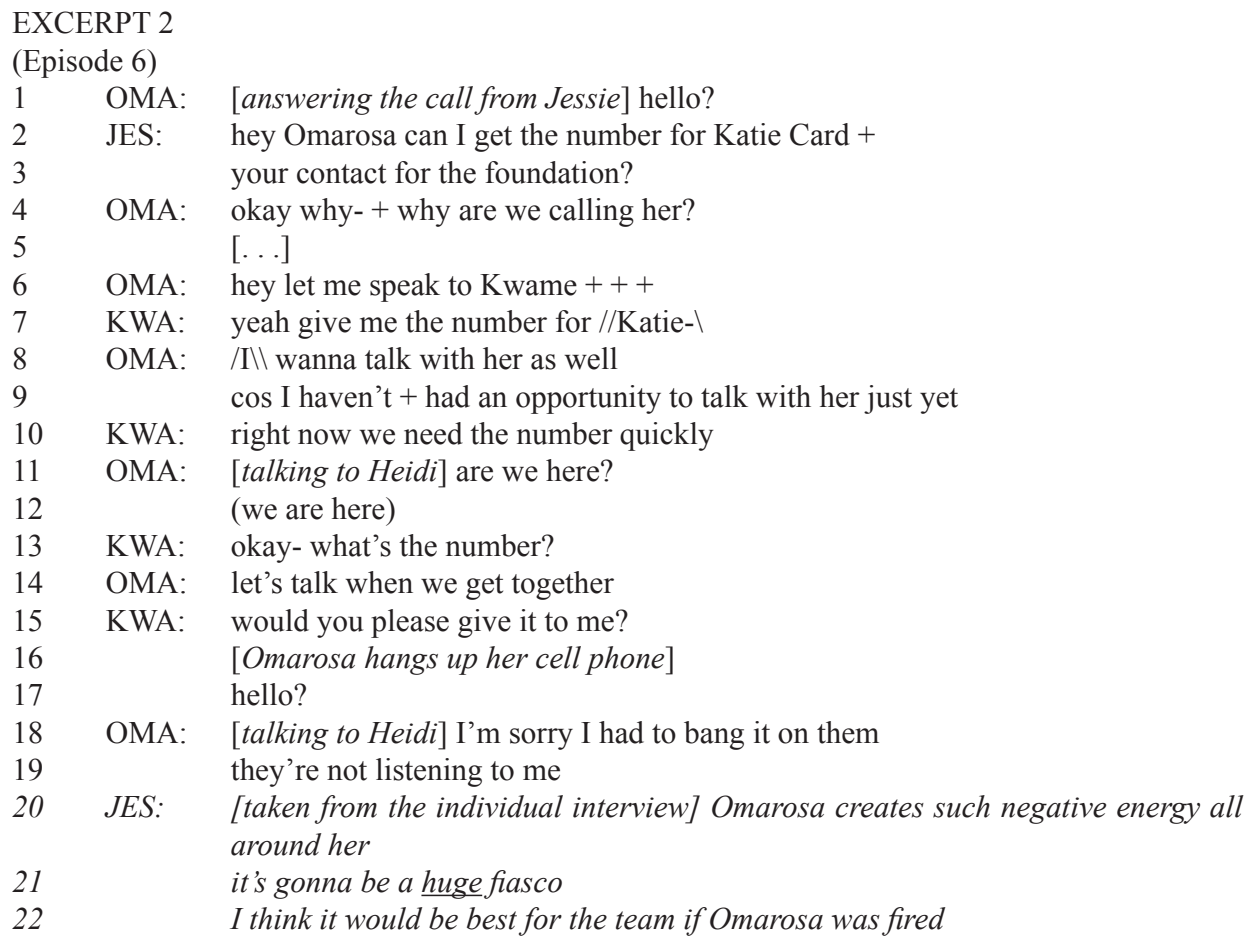

As we can see in the excerpt, Omarosa uses salient masculine discourse features as well as some features of a feminine discourse. Jessie asks Omarosa to get the number for Katie Card (line 2). But Omarosa questions the need for them to make the phone call rather directly by asking the question: why are we calling her? (line 4). Her question may be seen as face-threatening, as it implies that she does not see the point in calling. In line 6, Omarosa asks Jessie to pass the phone 
to Kwame. On picking up the phone, Kwame reiterates the request to get the number and issues a command in the form of an imperative: give me the number for Katie (line 7). In response, Omarosa states that she wants to talk with Katie (line 8), and provides a reason for it (line 9). Here, she appears to be making an executive decision, and in doing so, emphasizes her power and authority as project manager. Also, by stating her decision to call the person in charge of the foundation personally, she may further underline her status in the group. Note, however, that while Omarosa may seem uncooperative, her discourse can be said to be generally other-oriented. For example, she makes the suggestion using let's (line 14): let's talk when we get together, which can be interpreted as a cooperative offer. In other words, she does not directly refuse the request for the number; rather, she chooses to refuse to provide it through avoidance strategies.

It is also clear that Omarosa does not observe the etiquette of ending the telephone conversation: she hangs up her cell phone without closing the conversation properly, or politely, even though Kwame reiterates the request before the conversation is cut off. In line 18, she says explicitly to Heidi that I'm sorry I had to bang it on them. Her improper, or impolite, telephone behaviour could be coded as being stereotypically masculine, although she does acknowledge that she might appear rude (line 18), which may imply her awareness of breaking the expected norm of politeness and her orientation to relational aspects of the interaction.

In the excerpt, we can also see that Omarosa seems to make the decision of not giving the number to Kwame and Jessie solely based on her personal preference. In the telephone conversation, she does not explain why she refuses to give them the number, despite their repeated requests. Hence, Omarosa can be viewed as adopting a rather authoritarian style in 'doing leadership', although certain feminine discourse features are also evident. In particular, she is witnessed exercising and displaying her authority in a relatively explicit manner by imposing the decision on the group by authority and rejecting any possible negotiation. In response to Omarosa's predominantly masculine leadership style, Jessie notes in her individual interview that I think it would be best for the team if Omarosa was fired (line 22), expressing her disapproval of Omarosa's leadership style in very strong terms. Jessie also explains that Omarosa creates negative energy all around her (line 20) and produces a huge fiasco (line 21).

In the next excerpt, we shall see that the group is going to meet with a celebrity to discuss the arrangements of a charity auction. Omarosa is speaking to the whole group before the meeting begins.

\section{EXCERPT 3}

(Episode 6)

1 OMA: listen you all

2 regardless of what happens

3 we have got to come out of here with something

4 JES: [taken from the individual interview] Omarosa would jump in when I was speaking 
5

6

Here, Omarosa is witnessed as doing leadership in a predominantly masculine way, clearly orienting to the transactional goals of the meeting. In the excerpt, she first draws the attention of the members with the imperative listen and the directive pronoun you all (line 1). She goes on to state the objective of the meeting and her expectations in firm and strong terms: regardless of what happens we have got to come out of here with something (lines 2-3). Here, she uses the firm modal of obligation have got to (line 3) in stating the directive, which is a typically masculine way of giving instructions, albeit coupled with the use of the inclusive pronoun we to indicate shared responsibility, which shows an awareness of group orientation. And by saying regardless of what happens (line 2), she emphasizes that it is almost 'a must' for the group to reach an agreement by the end of the meeting. In so doing, she not only stresses the transactional goals, or the outcomes of the meeting, but also implies that any glitches in the process will not be tolerated for any reason. Here, we can see that she does leadership in an assertive and masculine style, with strong task orientation.

During the individual interview, Jessie shows her disapproval of Omarosa's way of doing leadership in the negotiation process. Specifically, Jessie thinks that Omarosa's controlling style adversely affects her ability to negotiate (line 5), which could eventually result in a negative impact on the outcome of the meeting. Overall, as seen in Excerpts 2 and 3, the use of masculine discourse features is judged very negatively, in spite of the fact that there are also some features of a feminine discourse. As a result of the use of a predominantly masculine speech style in doing leadership (and perhaps also partly due to her rudeness), Omarosa is subjected to negative evaluations from other contestants.

\subsection{Analysis of Kwame's leadership discourse}

I shall now turn to examine how the male project manager 'does leadership'. In the next below, Kwame deals with a potential crisis in the mixed-sex group in Episode 15. Heidi expresses her concerns to Kwame that she feels like she is not trusted by him. He is talking to Heidi, trying to put her mind at ease about her concerns.

\section{EXCERPT 4}

(Episode 15)

19 HEI: can I just express my concerns right now?

20 KWA: yeah

21 HEI: it's not personal + well it actually is

22 [coughs] this is what I have a problem with

I was in charge of meet and greet

I don't know if you don't //trust me 


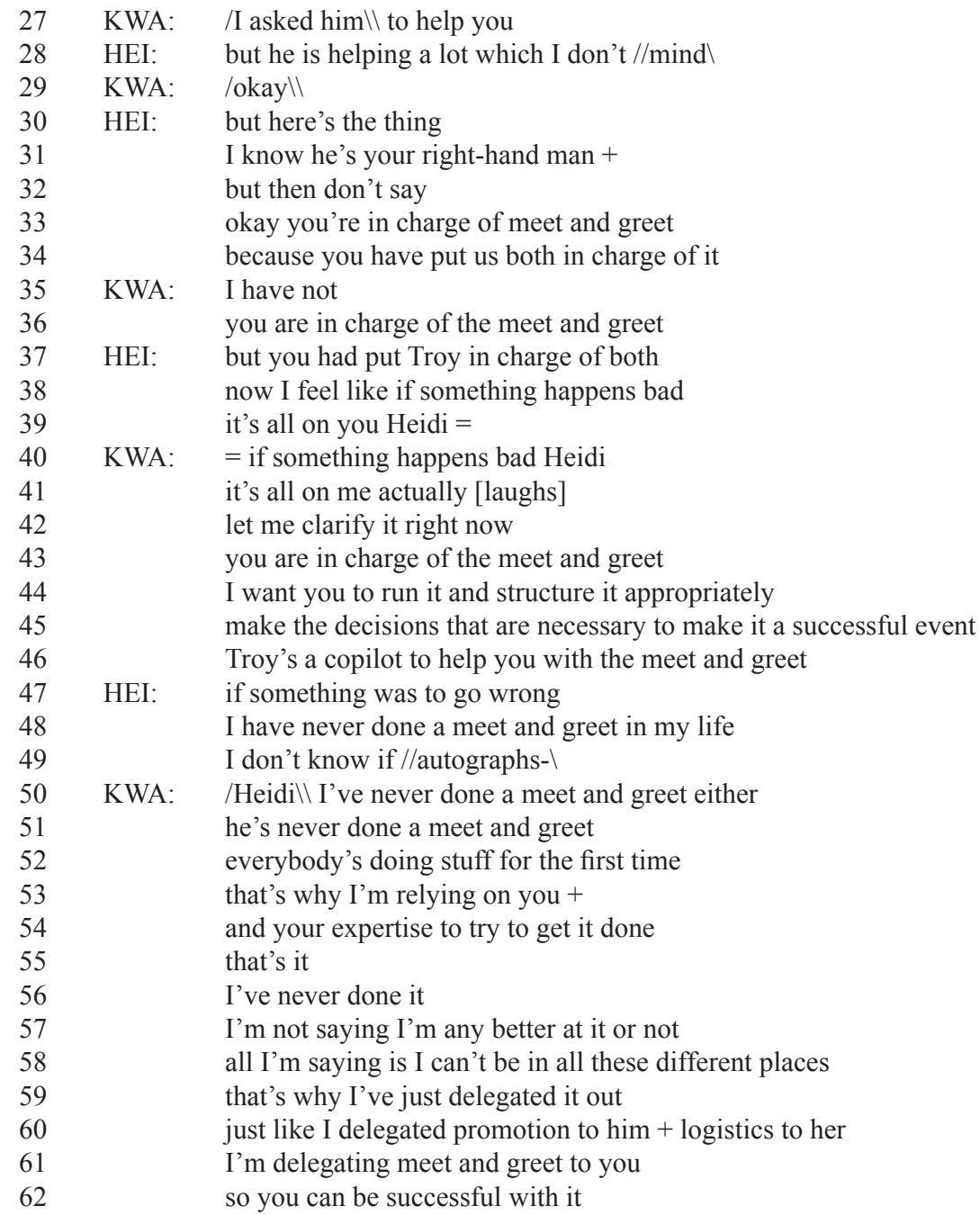

In the excerpt above, Kwame makes use of a combination of masculine and feminine discursive strategies in addressing Heidi's dissatisfaction skillfully, resolving the potential crisis within the group effectively. In an attempt to alleviate her concerns, Kwame explains that if something happens bad Heidi it's all on me actually (lines 40-41) in a humorous tone of voice. His laughter (line 41) serves to defuse the tensions at the time, projecting a less serious and relaxed atmosphere. In line 42, he begins his clarification with the metalinguistic statement: let me clarify it right now. By using the metadiscoursal clarify (line 42), he removes any possible ambiguity of the force of his utterance so that he could deal with her concerns right away. He then spells out her duties and responsibilities in the task as well as giving some direct and authoritative instructions to Heidi: you are in charge of the meet and greet (line 43) and I want you to run it and structure it appropriately (line 44 ). Here, while using typically masculine discourse strate- 
gies, he can also be viewed as empowering Heidi by giving her liberty to make decisions in organizing the meet and greet. In doing so, he shows his trust and faith in her ability in accomplishing the task successfully, thereby orienting to the relational aspects of the interaction.

In response to Heidi's concerns about messing things up (line 47), Kwame positively acknowledges and gives credits to Heidi's expertise, that's why I'm relying on you and your expertise to try to get it done (lines 53-54), drawing attention to her valued expertise in the group and paying attention to her positive face. Note that he attempts not to position himself as an expert or overtly display his authority even if he is the project manager. He also acknowledges the fact that I've never done it (line 56), thereby downplaying his own expertise and minimizing the power differential between Heidi and himself. Such verbal behaviour can be coded as features of a stereotypically feminine discourse. In addition, there is evidence of the use of rather assertive, typically masculine discourse: that's it (line 55). Kwame also attempts to position himself on an equal footing with the other members in the team by saying I'm not saying I'm any better at it or not (line 57). He then goes on to provide justifications for the importance of division of labor eloquently to Heidi (line 58-60), attempting to pacify Heidi's discontent and frustration. Towards the end of the interaction, Kwame reassures Heidi by reiterating that she is in charge of the meet and greet clearly (line 61). By saying so you can be successful with it (line 62), he displays his trust and confidence in Heidi that she is capable of running the event successfully.

It is noteworthy that Kwame handling of the situation is commended overtly by George who considers that Kwame is doing the job well (see Excerpt 5 below).

\section{EXCERPT 5}

(Episode 15)

\begin{tabular}{|c|c|}
\hline GEOR: & Kwame's handling it well \\
\hline 2 & I think it's by far a very difficult task to do \\
\hline 3 & he seems to have it fairly much under control \\
\hline 4 & putting all the pieces together \\
\hline 5 & and seeing that it runs smoothly is a real challenge \\
\hline 6 & I think Kwame's doing well \\
\hline
\end{tabular}

Overall, Kwame can be witnessed as drawing upon both masculine and feminine discourse features, and adopting a supportive and empowering style in 'doing leadership'. Rather than only focusing on getting things done, he also pays attention to the relational aspects of the interaction with Heidi. He addresses Heidi's concerns and dissatisfaction by providing reassurances and emphasizing the value of her skills being brought to the task. By paying attention to Heidi's positive face needs in softening her distress, Kwame secures her co-operation and her contributions to the group, whilst contributing to the accomplishment of the transactional goals by mixing both masculine and feminine discourse strategies.

In Excerpt 6 below, Kwame's group is faced with the task of picking one of the two artists that they will have to work with in the upcoming sales challenge, 


\section{and they are now having a group meeting in a restaurant with Omarosa, Heidi and Troy.}

\section{EXCERPT 6}

(Episode 9)

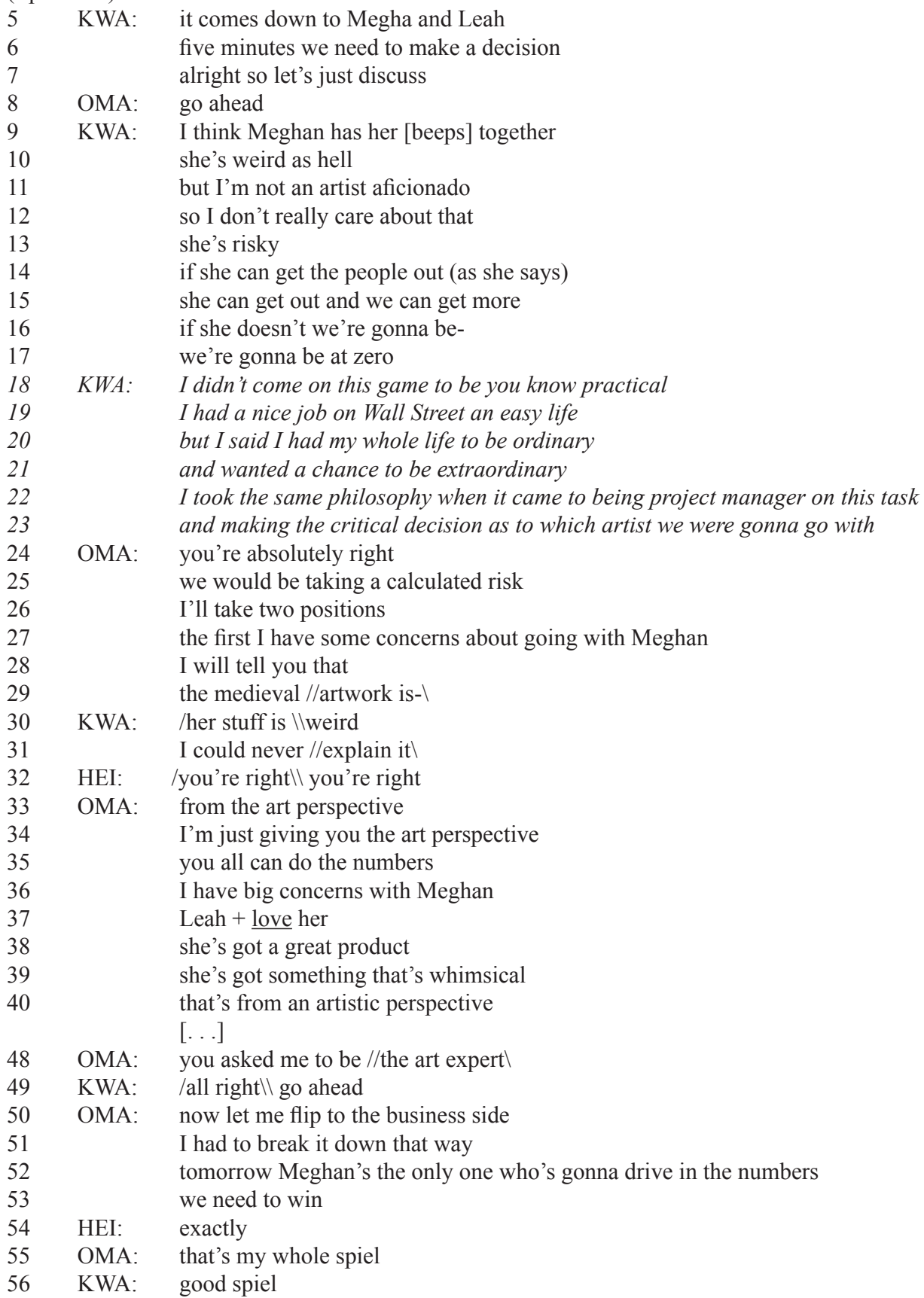




$\begin{array}{lll} & & {[\ldots]} \\ 57 & \text { KWA: } & \text { because //art is all about risk } \ \\ 58 & \text { TROY: } & \text { /I'm just kidding } \backslash \\ 59 & \text { KWA: } & \text { art is all about risk } \\ 60 & \text { KWA: } & \begin{array}{l}\text { we are officially selecting Meghan [laughs] } \\ \text { let's take a risk }\end{array} \\ 62 & \text { TROY: } & \text { we gotta break Amy's luck } \\ 63 & \text { KWA: } & \text { risk on three } \\ 64 & \text { ALL: } & \text { one two three }\end{array}$

In this excerpt, Kwame can be witnessed as performing his leader identity by drawing upon a range of discourse strategies which may be indexed for masculinity and femininity. For example, Kwame starts off the meeting with a clear objective of the meeting by stating the two choices they have got: it comes down to Meghan and Leah (line 5). He also spells out the amount of time within which they need to make a decision in an explicit and firm manner: five minutes we need to make a decision (line 6). Here, the orientation to the transactional goals of the meeting can be ascribed to masculinity. Kwame goes on to initiate the discussion with the standard discourse marker alright (line 7), followed by a suggestion: so let's just discuss (line 7). Here, he uses the collective let's (line 7) and just (line 7) to minimize status difference and establish solidarity with the other members of the group, which can be seen as typical of a feminine discourse style. Omarosa's 'yes' response, go ahead (line 8), provides support for his suggestion. Kwame then goes on to express his view on Meghan, pointing out the advantages and disadvantages of picking Meghan as the artist (lines 13-17). Here, instead of making the decision right away, Kwame points out his personal observation about Meghan that she is risky (line 13), thereby leaving the option open to the group's decision. His behaviour here serves to facilitate further discussion among the group members and avoid appearing autocratic in the process of decision making. Notice also that he uses the inclusive pronoun we (lines 15, 16 and 17) to emphasize group solidarity and shared responsibility in the task, thereby showing an orientation to the relational goals of 'doing leadership'.

An individual interview with Kwame (lines 18-23) is inserted in the middle of the meeting, where he is given the chance to spell out his philosophy (line 22) about taking risks and about leadership in general. He points out that I had my whole life to be ordinary and wanted a chance to be extraordinary (line 21), implying that he enjoys taking risks and accepting challenges in his life. By saying I didn't come on this game to be you know practical (line 18), Kwame not only justifies the decision to take risks in the current task, but also presents himself as capable of dealing with risks and challenges. Here, Kwame can be seen to be constructed as an adventurous and audacious leader, which accords with the traditional image of a male 'heroic' leader (see Sinclair 1998).

It is noteworthy that Kwame's collaborative style of discourse is also evident in the interaction and is characteristic of a stereotypically feminine leadership style. In lines 24-29, Omarosa points out some of her concerns about picking 
Meghan as the artist. Before Omarosa completes her utterance the medieval artwork is- (line 29), Kwame provides his agreement by overlapping with Omarosa's utterance and saying her stuff is weird (line 30) almost simultaneously. His interruption here could be viewed as collaborative, rather than disruptive, in the sense that it completes Omarosa's yet-to-be-completed utterance about Meghan's artist style. By doing so, Kwame shows that he and Omarosa are on the same wavelength and displays his agreement with her concerns.

Further, Kwame displays his supportive behaviour which can be placed towards the feminine end of 'doing leadership'. For example, when Omarosa finished spelling out her ideas as to who to pick as the artist by saying that's my whole spiel (line 55), Kwame immediately ratifies her ideas and provides approval by saying good spiel (line 56). By showing his approval and appreciation, he achieves the relational goals of maintaining team morale and shows that he pays close attention to Omarosa's face needs. Note also that he recycles Omarosa's word spiel in giving his evaluative comment good spiel (line 56). By using repetition, Kwame may also be viewed as sending a meta-message of involvement (Tannen 1987). Kwame later gives his reassurance to the group by saying that art is all about risk twice (lines 57 and 59), in an attempt to convey a sense of confidence in the choice they just made and alleviate their concerns about the risks involved. In the end of the excerpt, after Troy says that we gotta break Amy's luck (line 62), Kwame boosts the team morale by initiating a hands-in with the group chant risk on three (line 63). Here, his verbal behavior serves to enhance the cohesiveness and esprit de corps of the team, thereby achieving the relational aspects of doing leadership.

It seems clear from the excerpt above that Kwame enacts his identity as a leader by using a range of verbal behaviours and discourse strategies which can be ascribed to both masculinity and femininity. He gives approval to others' ideas, expresses his support to facilitate the discussion, and pays attention to both the relational and transactional aspects of the interaction. Whilst he stays mostly in the background, he runs the meeting smoothly, and decisions are reached at the end of the meeting.

\section{Discussion and conclusion}

Overall, the analysis shows that both project managers are witnessed as using discourse features that can be ascribed to masculinity and femininity in 'doing leadership'. In addition to employing discourse elements which correspond to their own gender, they also make use of elements of speech styles which are stereotypically associated with the other gender. In other words, they are engaged in 'mixing' masculine and feminine discourse strategies, thereby challenging the stereotypical gendered speech norms in performing leadership.

Based on the analysis above, the representations of gender and leadership in The Apprentice can be seen to contest the exclusive association of a particular 
gendered leadership style with one gender and the well-established popular belief about gender differences of 'doing leadership' which has been perpetuated by gender ideologies and stereotypes (Cameron 2003, 2007; Talbot 2010). Such representations may serve to de-stabilize essentialist notions such as 'men's leadership style' and 'women's leadership style', and weaken the dichotomous conceptions of men's and women' $s$ leadership styles by showing intra-gender differences in the enactment of leadership and a wide range of options available in 'doing leadership' discursively. In particular, the use of elements of a masculine speech style by Omarosa in 'doing leadership' can be seen to contribute to what Holmes (2006: 67) describes as 'de-gendering' of discourse strategies. In other words, the masculine discourse features employed by Omarosa are merely "tools of leadership discourse, and not exclusively of male discourse" (Holmes 2006: 67; see also Schnurr 2010).

However, as evident in the analysis, the mixing of masculine and feminine discourse strategies in 'doing leadership' seems to be evaluated very differently for Omarosa and Kwame. While the male manager is commended and judged positively by other contestants, the female manager seems to be judged to be overly aggressive. As can be seen in the analysis, Omarosa's deviation from the norms of feminine verbal behaviour attracts criticisms from her team members. It appears that violating stereotypical expectations of gender-appropriate verbal behaviours may come at a social cost. In particular, it may be considered inappropriate for women to use normatively masculine discourse strategies in enacting power and authority at work, and if they do so, they are likely to be subjected to negative evaluations. It may therefore be suggested that women in general may be under more constraints in enacting leadership than men when they transgress stereotypical gendered expectations for their speech patterns. In Bergvall's (1996: 193) study on the construction of gender identity by female engineering students, she argues that these students "are particularly vulnerable to attack when their attempts to enact apparently androgynous behaviours result in retaliatory acts". In other words, female managers may be expected to display at least certain feminine speech characteristics in order to be accepted as leaders and to be judged positively simultaneously.

It is also interesting to note that the representations of gender and leadership in The Apprentice seem to reflect the stereotypical expectations of gender-appropriate behaviours in workplace communication. Specifically, the different evaluations of Omarosa's and Kwame's enactment of leadership may possibly be explained by the influence of stereotypical gendered discursive norms and the existence of 'double standards' with regards to the expectations for male and female professionals in the workplace. As Thimm et al. (2003) suggest, men and women professionals are often measured by different standards, and stereotypical expectations tend to restrict women's interactional behaviour more than men's. In most cases, while men are allowed to use a greater range of acceptable verbal behaviours, women are sanctioned into less flexible ways of behaving. In the analysis, while Omarosa appears to be penalized for violating the norms of feminine speech behaviour for 
doing leadership, Kwame does not seem to be subjected to such stringent gendered norms but is allowed to make use of a mixture of differently gendered discursive features in his speech. One plausible reason may be that it is usually seen as unproblematic for male managers to break stereotypically gendered speech norms as it is for female managers. In addition, as feminine discourse is not viewed as a naturalized part of the self for men, it is rewarded as an occupational resource (Peck 2006). As a result, male managers who make use of some feminine discourse strategies may be viewed as making an extra effort in doing leadership, and as such, are perceived positively. Indeed, since leadership has traditionally been closely associated with men, the incorporation of feminine discursive characteristics into the leadership style by a male manager may not raise serious questions about his identity as a leader. As Thimm et al. (2003: 536) suggest, "men [often] appear as the 'default' gender in successful or leading positions".

Furthermore, the study found that the skilful use of a combination of masculine and feminine discourse features in 'doing leadership' is presented most favourably in the reality TV show. What is noteworthy is that Kwame's use of both masculine and feminine discourse strategies in enacting leadership is judged positively by other members in the show. His way of 'doing leadership' through discourse can be referred to as a 'wide-verbal-repertoire speech style' (Case 1993, 1994; Holmes 2006), i.e., the combination of different proportions of masculine and feminine speech characteristics. As Barrett (2004: 400) suggests, "a masculine approach is most effective if it includes a feminine element". Jule (2008: 62) also makes the point that corporate organizations are "increasingly valuing the blending of various leadership styles", since they recognize certain feminine traits, such as the ability to share power and to build consensus, as positive traits regardless of one's sex. In other words, The Apprentice can be seen to portray positively leadership discourse that involves the skilful and flexible use of both masculine and feminine speech strategies. Interestingly, such representations are largely consistent with the recent findings of what constitutes effective leadership (cf. Baxter 2010).

To conclude, this article has presented a case study of taking a discourse approach to analyzing the representations of leadership, gender and workplace communication in media texts. It must be noted, however, that the analysis of the two project managers' leadership styles should not be considered generalizable to other contestants in the entire show, or to other reality TV shows. In addition, caution must be exercised when interpreting the impact of gender norms on the evaluation of the leadership performance of other male and female managers in the TV show, since this paper only looked at one male and one female project manager. Further research is needed to explore the representations of gendered discourses and workplace communication in other forms of media. It would also be worthwhile to pursue further research by adopting a multi-disciplinary perspective through drawing on methodologies from various disciplines such as discourse analysis, organizational studies, psychology and sociology, given the scarcity of research on the media representations of leadership and gender. 


\section{Appendix: Transcription Conventions}

\begin{tabular}{|c|c|}
\hline yes & underscore indicates emphatic stress \\
\hline [laughs] & paralinguistic features in square brackets \\
\hline+ & pause of up to one second \\
\hline \multicolumn{2}{|l|}{$\mathrm{xxx} / / \mathrm{xxxxx} \backslash \mathrm{xxx}$} \\
\hline $\mathrm{xxx} / \mathrm{xxxxx} \| \mathrm{xxx}$ & simultaneous speech \\
\hline$=$ & latching between the end of one turn to the start of the next \\
\hline (3) & pause of specified number of seconds \\
\hline$($ ) & unintelligible word or phrase \\
\hline (hello) & transcriber's best guess at an unclear utterance \\
\hline$?$ & raising or question intonation \\
\hline- & incomplete or cut-off utterance \\
\hline$[\ldots]$ & text omitted \\
\hline [comments] & editorial comments italicized in square brackets \\
\hline words in italics & commentary from behind-the-scene individual interviews \\
\hline
\end{tabular}

\section{References}

Barrett, Mary (2004) "Should they learn to interrupt? Workplace communication strategies Australian women managers forecast as effective". Women in Management 19 (8), 391-403.

Baxter, Judith (2010) The Language of Female Leadership. Basingstoke: Palgrave Macmillan.

Bergvall, Victoria (1996) "Constructing and enacting gender through discourse: Negotiating multiple roles as female engineering students". In: Bergvall, Victoria, Janet Bing and Alice Freed (eds.) Rethinking Language and Gender Research: Theory and Practice. New York: Longman, 173-201.

Butler, Judith (1990) Gender Trouble: Feminism and the Subversion of Identity. London: Routledge.

Cameron, Deborah (2003) "Gender and language ideologies". In: Holmes, Janet and Miriam Meyerhoff (eds.) The Handbook of Language and Gender. Oxford: Blackwell, 447-467.

Cameron, Deborah (2007) "Dreaming of Genie: Language, gender difference and identity on the web". In: Johnson, Sally and Astrid Ensslin (eds.) Language in the Media. London: Continuum, 234-249.

Case, Susan (1993) "Wide-verbal-repertoire speech: Gender, language, and managerial influence". Women's Studies International Forum 16 (3), 271-290.

Case, Susan (1994) "Gender differences in communication and behaviour in organizations". In: Davidson, Marilyn and Ronald Burke (eds.) Women in Management: Current Research Issues. London: P. Chapman, 144-167.

Coates, Jennifer (1997) “One-at-a-time: The organization of men's talk". In: Johnson, Sally and Ulrike Meinhoff (eds.) Language and Masculinity. Oxford: Blackwell, 107-129.

Coates, Jennifer (2004) Women, Men, and Language: A Sociolinguistic Account of Gender Differences in Language. Harlow and New York: Pearson Longman.

Evans, Jessica (2005) "Celebrity: What's the media got to do with it?" In: Evans, Jessica and David Hesmondhalgh (eds.) Understanding Media: Inside Celebrity. Maidenhead: Open University Press, $1-10$.

Gill, Rosalind (2006) Gender and the Media. Cambridge: Polity Press. 
Hearn, Jeff and Wendy Parkin (1989) "Women, men, and leadership: A critical review of assumptions, practices, and change in the industrialized nations". In: Adler, Nancy and Dafna Izraeli (eds.) Women in Management Worldwide. London: M. E. Sharpe, 17-40.

Holmes, Janet (1995) Women, Men and Politeness. London: Longman.

Holmes, Janet (2006) Gendered Talk at Work: Constructing Gender Identity through Workplace Discourse. Oxford: Blackwell.

Holmes, Janet and Maria Stubbe (2003) Power and Politeness in the Workplace. London: Pearson.

Holmes, Janet and Meredith Marra (2010) "Femininity, feminism and gendered discourse". In: Holmes, Janet and Meredith Marra (eds.) Femininity, Feminism and Gendered Discourse. Newcastle upon Tyne: Cambridge Scholars, 1-18.

Holmes, Janet, Stephanie Schnurr, Angela Chan and Tina Chiles (2003) "The discourse of leadership". Te Reo 46, 31-46.

Jule, Allyson (2008) A Beginner's Guide to Language and Gender. Clevedon: Multilingual Matters. Litosseliti, Lia (2006) Gender and Language: Theory and Practice. Oxford: Arnold.

Marra, Meredith, Stephanie Schnurr and Janet Holmes (2006) "Effective leadership in New Zealand workplaces". In: Baxter, Judith (ed.) Speaking Out: The Female Voice in Public Contexts. Basingstoke: Palgrave, 240-260.

Martin Rojo, Luisa and Concepcion Gomez Esteban (2005) "The gender of power: The female style in labour organizations". In: Lazar, Michelle (ed.) Feminist Critical Discourse Analysis. London: Palgrave, 61-89.

Matheson, Donald (2005) Media Discourses: Analysing Media Texts. Berkshire: Open University Press.

Ochs, Elinor (1992) "Indexing gender". In: Duranti, Alessandro and Charles Goodwin (eds.) Rethinking Context: Language as an Interactive Phenomenon. Cambridge: Cambridge University Press, 335-358.

Peck, Jennifer (2006) "Women and promotion: The influence of communication style". In: Barrett, Mary and Marilyn Davidson (eds.) Gender and Communication at Work. Hampshire: Ashgate, $50-66$.

Ross, Karen (2010) Gendered Media: Women, Men, and Identity Politics. Lanham, MD: Rowman and Littlefield.

Schnurr, Stephanie (2009) Leadership Discourse at Work: Interactions of Humour, Gender and Workplace Culture. Basingstoke: Palgrave Macmillan.

Schnurr, Stephanie (2010) "Decision made - let's move on: Negotiating gender and professional identity in Hong Kong workplaces". In: Muehleisen, Susanne, Markus Bieswanger and Heiko Motschenbacher (eds.) Language in its Socio-cultural Context. Frankfurt am Main: Peter Lang, 111-136.

Sinclair, Amanda (1998) Doing Leadership Differently: Gender, Power and Sexuality in a Changing Business Culture. Melbourne: Melbourne University Press.

Sunderland, Jane (2004) Gendered Discourses. London: Palgrave Macmillan.

Sung, Chit Cheung Matthew (2011) "Doing gender and leadership: A discursive analysis of media representations in a reality TV show". English Text Construction 4 (1), 85-112.

Sung, Chit Cheung Matthew (2012) "Exploring the interplay of gender, discourse, and (im)politeness". Journal of Gender Studies 21 (3), 285-300.

Sung, Chit Cheung Matthew (2013) "Language and gender in a US reality TV show: An analysis of leadership discourse in single-sex interactions". Nordic Journal of English Studies 12 (2), 25-51.

Talbot, Mary (2010) Language and Gender: An Introduction. Cambridge, UK: Polity Press.

Tannen, Deborah (1987) "Repetition in conversation: Towards a poetics of talk". Language 63 (3), $574-605$.

Thimm, Caja, Sabine Koch and Sabine Schey (2003) "Communicating gendered professional identity". In: Holmes, Janet and Miriam Meyerhoff (eds.) The Handbook of Language and Gender. Oxford: Blackwell, 528-549. 
Chit Cheung Matthew Sung recently received a PhD in Linguistics from Lancaster University, UK. He also holds a first-class degree and a Master of Philosophy in English from the University of Hong Kong. His research interests include gender and discourse, language and identity, sociolinguistics, English as a lingua franca, and second language education. He has published in these areas in several international journals, including English Today, Changing English, English Language Teaching Journal, English Text Construction, JALT Journal, Journal of Gender Studies, and The Language Teacher.

Address: Chit Cheung Matthew Sung, PhD, Department of Linguistics and English Language, County South, Lancaster University, Lancaster, LA1 4YT, UK [email: c.sung@lancaster.ac.uk] 
